\title{
Entelektüel Sermaye ve İnsan Unsurunun Sürekli Gelişimi için Alternatif Bir Yaklaşım: İnsana Yatırım Standardı (IIP)
}

\section{An Alternative Approach to Permanent Improvement of Intellectual Capital and Human Resources: Investors in People (IIP)}

\author{
Mehmet Merve ÖZAYDIN, Gazi Üniversitesi, Türkiye, ozaydin@gazi.edu.tr \\ Emine İLHAN, İller Bankası A.Ş., Türkiye, eilhan@ilbank.gov.tr \\ Mehmet Ragıp BAYRAK, İller Bankası A.Ş, Türkiye, mrbayrak@ilbank.gov.tr
}

\begin{abstract}
Öz: Küresel ekonomide son yıllarda yașanan gelișmeler, uluslararası rekabeti tetikleyerek bilgi ekonomisi ve firmaların entelektüel sermaye unsurları arasında yer alan insan sermayesinin önemini artırıcı bir etki yaratmıştır. Bu doğrultuda özellikle insan kaynağına değer verme noktasında gelişmiş ülkeler yaşam boyu eğitim ve ögrenimin teşvik edilmesi hususunda ön ayak olmuşlardır. IIP Standardl, 1990 yllında İngiltere'de Ulusal Eğitim Görevlileri Birliği (National Training Task Force) tarafindan paydaşlardan uzman kişilerin katkalarılyla iş süreçlerinin personelin geliştirilmesi yoluyla düzenlenmesi ve iş performansinın arttırlmasına yönelik ulusal bir çerçeve belirlemek amacıvla gelistirilmiștir. Cerçeveyi olușturan göstergeler İngiltere'nin önde gelen șirketlerinin iç işleyişleri incelenerek belirlenmişstir. IIP Standardı yirmi yılı aşkın süredir İngiltere'de milli eğitim politikasının kalıcı nitelikli özelliklerinden birisi olmuștur. (Gloster ve diğerleri, $2010,1)$ Íngiltere'de kamu kurumlarından KOBİ niteliğindeki ișletmelere kadar geniss bir yelpazeyi kapsayan IIP Standardl, insan odakl yönetim stratejisini benimseyerek kurumsal vizyonun paylaşılması ve çalışanların mesleki eğitim-öğrenim düzeylerinin yükseltilmesi yoluyla motivasyon ve verimlilik artışının sağlanmasını öngörmektedir. Standart, moral ve motivasyon düzeyi yüksek çalışanlardan oluşan bir örgütün orta ve uzun vadede kurumsal performans düzevinde artıs sağlayacağını varsaymaktadır. Bu çalısmanın amacl, dünyadan alınan örneklerle işletmelerin ve dolaylsılyla ülkelerin küresel rekabet gücü üzerinde IIP Standardınin potansiyel etkisini incelemektir.
\end{abstract}

Anahtar Sözcükler: Insana Yatırım Standardı (IIP), Entelektüel Sermaye, İnsan Sermayesi, Kurumsal Performans, Bilgi Ekonomisi.

Abstract: Recent develeopments ongoing global economy triggered to international competitiveness. In this manner, as major component of knowledge-based economy and intellectual capital, importance of human capital increased. Particularly, developed economies that realize the situation, encourage life-long education and learning to add value their human capital. Investors in People (IIP) was developed in 1990 by the National Training Task Force, with expert input from stakeholders, to set out a national framework aiming to link the processes of setting business objectives with staff development to improve business performance. The framework indicators were developed from an examination of the internal practices of some of the UK"s leading companies. (Gloster et al., 2010, 1) In addition to cover corporate priorities and purposes in public services, companies, SMEs and other foundations, IIP focuses human oriented management strategy by increasing motivation, developing skills and shares corporate vision and values with all level of workers in UK. IIP assumes that high level of workers motivation leads to improve corporate performance. In this study, we aim to research corporate functions and potential benefits of IIP by examining the examples of world countries.

Keywords: Investors in People (IIP), Intellectual Capital, Human Capital, Corporate Performance, Knowledge-Based Economy.

\section{Giriş}

Dünya ekonomisi, son otuz yıllık yakın geçmişe bakıldığında gelişen ve yaygınlaşan iletişim araçlarının öncülüğünde sermaye ve bilgi akışının sınır tanımaksızın hızlandığı, bunun sonucunda da uluslararası rekabetin arttığı bir görünüm sergilemektedir. Başlıca üretim faktörlerini oluşturan sermaye, doğal kaynak, girişimci, teknoloji ve emek faktörleri küreselleşen ekonomik şartlar altında hareketliliği hızla artış gösteren bir hâle bürünmüştür. Emek faktörünü teşkil eden insan sermayesi, işletmelerin entelektüel sermayesinin altyap1 unsurunu oluşturmuş ve kurumsal performansı etkileyen finansal olmayan performans göstergeleri arasında yer almıştır.

Personel yönetimi ile başlayan ve bir süreç içerisinde entelektüel sermaye unsuru bünyesinde yer alan insan sermayesinin temeline indiğimizde Sanayi Devrimi'ne bağlı olarak ortaya çıkan topraktan makineye geçişe kadar etkilere ulaşabiliriz. Aynı zamanda yönetim kavramının ortaya çıkışı ve buna bağlı olarak şekillenen yönetim kuramlarının oluşturulması insan gücü olarak başlayan bu süreci personel yönetimi anlayışına dönüştürmüştür. Zamanla örgütlerde yer alan insan ögesinin bir maliyet unsuru olmasından ziyade elde edilmesi ve geliştirilmesi gerekli bir kaynak anlayışına geçilmesiyle 1980'li yıllarda personel yönetiminden insan kaynakları yönetimine doğru bir kayma olmuştur. 1990'lardan itibaren ise taklit edilmesi en zor kaynak olarak gösterilen insan kaynaklarına yapılan yatırımlar nedeniyle insan önemli bir sermaye unsuru olarak ele alınmış ve entelektüel sermaye unsurları içerisinde insan sermayesi olarak ifade edilmiştir. Bu süreç içerisinde sanayi toplumları giderek yerini bilgi toplumlarına bırakmışlardır. 
Yaşanan bu gelişmelere paralel olarak ortaya çıkan teknolojik ilerlemeler ve bu ilerlemelere bağlı olarak şekillenen yeni maddi olmayan unsurlar sonucunda kendisini sürekli olarak yenileyen ve "bilgi ekonomisi" olarak ifade edilen yeni bir ekonomik yapı meydana gelmiştir. Bu unsurların birçoğu daha önceden var olmayan ya da var olup da üzerinde yeterince durulmayan varlıklardır. İşletmeler sahip oldukları maddi duran varlıkların değerinden çok daha fazlasına sahip topluluklar olarak bilgi ekonomisinin de getirdiği ekonomik yapılanmanın da etkisiyle maddi olmayan varlıkları olmaksızın faaliyetlerini sürdüremeyeceklerini anlamışlardır. Bu sebeple işletme yapısı içerisinde maddi olmayan varlıkların önemi maddi varlıklara oranla giderek artmaktadır. (Ercan, Öztürk ve Demirgüneș, 2003, 96) Bu süreç içerisinde, gelişmiş ülkeler başta olmak üzere birçok ülke değisşen ve artan rekabet koşullarına uyum sağlayabilmek adına yaşam boyu öğrenimi teşvik etmeye başlamış ve rekabet edilebilirliklerini sürdürebilmek adına emek faktörü üzerinden verimlilik ve etkinlik artışı sağlamaya çalışmıştır. $\mathrm{Bu}$ amaçla alternatif olabilecek yeni yöntemlerin geliştirilmesine yönelik araştırmalar daima gündemde olmuştur. $\mathrm{Bu}$ araştırmaların önemlilerinden ve bu çalışmanın da temelini oluşturan IIP Standardı, 1990'lı yılların başında İngiltere'de, insan kaynakları yönetimi açısından ortaya konulmuş ve ülkede eğitim-öğretim politikalarının şekillenmesini sağlamış önemli bir gelişmedir. 1990'l yıllar boyunca akreditasyon verilerek gözetim ve denetimi yapılmış olan standart, ortaya koyduğu çerçeve içerisinde gösterdiği esneklik sayesinde İngiltere'de büyüklüğü ve faaliyet konusu fark etmeksizin işletmeler arasında yaygınlık göstermiştir.

$\mathrm{Bu}$ çalışmada öncelikle IIP Standardı, işletmelerin insan kaynakları yönetimi politikaları ve kurumsal performansa etkileri incelenmekte ve küresel ekonominin önemli aktörlerinden İngiltere'de bu bağlamda elde edilen sonuçlar ele alınmaktadır. Ayrıca kültür odaklı bir standart olduğu için ülkeler arası transferleri gerçekleştirilirken de organizasyonlar arası kültür farklılıkları gözetilerek standart gösterge ve kriterleri de buna göre belirlenmelidir. İngiltere merkez odaklı olarak ortaya çıkan IIP akreditasyonu kültür odaklı olarak yön değiştirmesi niteliği ile Türkiye'de de işletmeler açısından uygulama alanı bulmaktadır ve yapılan bu çalışma Türkiye'deki uygulamalara da 1şık tutacaktır.

\section{Entelektüel Sermaye ve İnsan Sermayesi}

Gelişen bilgi ekonomisi sürecinde, örgütsel anlamda entelektüel sermayenin ilk olarak Thomas Stewart tarafindan 1991 yılında "Beyin Gücü" makalesi ile gündeme getirildiği bilinmektedir. Bu makalede entelektüel sermaye "işletmeye piyasada rekabet avantajı sağlayan, işletme çalışanlarının bildiği her şeyin toplamı" olarak tanımlanmıştır. (Yereli ve Gerşil, 2005, 18) Entelektüel sermayeyi meydana getiren unsurlar, insan sermayesi, yapısal sermaye, ilişki sermayesi, müşteri sermayesi, rekabetçi sermaye, tedarik kaynağı sermayesi, topluluk sermayesi, mevzuat sermayesi ve anlaşma sermayesi gibi çok farklı şekillerde ele alınabilmektedir. (Ercan, Öztürk ve Demirgüneş, 2003, 110)

T.Stewart, 1997 yılında yayınlanan "Entelektüel Sermaye; Örgütlerin Yeni Zenginliğı’” adlı kitabında ise entelektüel sermayeyi, elde edilmiş kullanışlı bilgi olarak tanımlamakta ve bunun örgütün süreçlerini, teknolojilerini, patentlerini, işgörenlerin becerileri ve müşteriler, tedarikçiler ve diğer ilişkili taraflar hakkındaki bilgileri içerdiğini belirtmektedir. En genel yönüyle entelektüel sermaye varlıkları dört grup altında toplanmaktadır: (Yereli ve Gerşil, 2005, 18)

- Ticari marka; patent, telif hakkı gibi düşünsel-entelektüel mülkiyeti kapsayan varlıkları içermektedir.

- Tüketici bağlllığı; iç sistemlerden kazanılan güç, yönetim ve iş süreci, şirket kültürü gibi organizasyona iç güç veren varlıkları içermektedir.

- Tekrarlanan işler; bilişim ağı kapasitesi, işle ilgili bilgi, yetenekler, organizasyon ve bunun gibi örgütte çalışanların ortaya koyduğu varlıkları içermektedir.

- Pazar bölümünde işletmeye güç veren varlıklar ise insan merkezli varlıklarla yönetmeye yönelik taktik ve stratejiler ile ilgili olan faaliyetler ve bilgi yönetimi içerisinde irdelenir. Tipik olarak benzer yetenekler, know-how, eğitim, tecrübelerden öğrenim ve benzeri konuları kapsar.

Annie Brooking, Göran Ross ve Nick Bontis entelektüel sermayeyi, kendini oluşturan bileşenlerin bir bütünü olarak tanımlamaktadırlar. (Yereli ve Gerşil, 2005, 18) Şekil 1'de entelektüel sermayeyi oluşturan unsurlar literatürde yapılan sınıflamalar dikkate alınarak belirlenmiştir. Entelektüel sermayenin bileşenlerinin temel unsuru olan insan ve insan sermayesi, entelektüel sermayenin değerini arttırmak amacıyla yatırım yapılması gereken başlıca unsur olmaktadır. Değere dayalı yönetim süreçlerinin odak noktası olduğu entelektüel sermaye rekabet üstünlüğü elde edebilmek adına sürekli iyileştirilmeli, geliştirilmeli ve değeri arttırılmalıdır. IIP Standardının amacı doğrudan insan unsuru üzerinden kurumsal amaç ve hedeflere ulaşmak olduğu için başarılı bir şekilde uygulanması halinde entelektüel sermaye üzerinde değer arttırıcı bir etki oluşturabilmektedir.

Entelektüel sermaye unsurları içerisinde çoğu zaman tanımlanması en zor sermaye unsuru olarak kabul edilebilen insan sermayesi, firma çalışanlarının sahip olduğu bilgi düzeyi, yetenek ve deneyimlerinin değerini ifade etmekte olup yenilik ve yenilenme sürecinin temel hareket noktasıdır. 


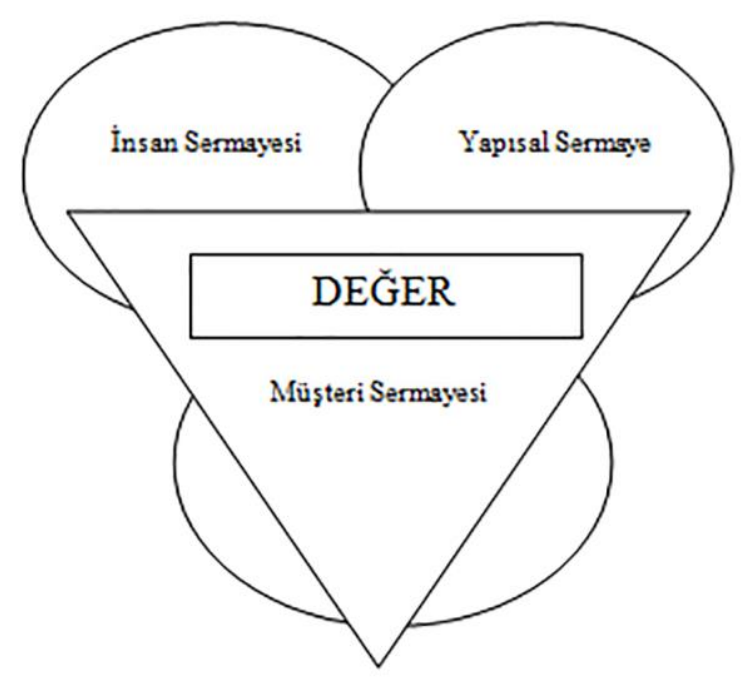

\section{Şekil 1. Entelektüel Sermayenin Unsurları}

Kaynak: Yereli ve Gerşil, 2005:18.

Literatürde farklı tanımları olan insan sermayesi genel olarak; işletme çalışanlarının bireysel olarak kendilerine verilen görevleri yerine getirebilmeleri için sahip oldukları ve dolayısıyla kullandıkları bilgilerin, yeteneklerin ve yaratıcılık özelliklerinin bir arada toplanmış halidir. Bu sermaye türü ayrıca işletmenin sahip olduğu değerleri, işletme kültürünü ve felsefesini de içine alır. (Çetin, 2005, 361) İşletme insan sermayesini sahiplenemez, çünkü bu sermaye işletme çalışanlarına aittir. İnsan sermayesi; doğal yetenek, eğitim ve deneyim sonucu kişinin sahip olduğu yaratıcı güçtür. Gratham'a göre insan sermayesi; işletmenin sorunlarını çözmek için sahip olduğu toplam insan yeteneğidir. Bir başka deyişle bir işletmenin insan sermayesi; çalışanlarının bilgilerini işletmenin sorunlarına uygulayabilme yeteneğidir. Luthy’e göre insan sermayesi; insanın kendisidir. Bu yüzden örgütler insan sermayesine sahip olamazlar, onu ancak kiralayabilirler. İnsan sermayesi, çalışanlar ayrıldıklarında işletmeden ayrılır. İnsan sermayesi, bir örgüt için yaratıcılık ve yenilik ile ölçülebilecek olan örgütün insan kaynağının ne derece etkin kullanıldığını içermektedir. (Çetin, 2005, 362) Diğer yandan Nobel ödüllü ekonomist T.W. Schultz insan sermayesi kavramının önemini şu şekilde açıklamaktadır: (Ercan, Öztürk ve Demirgüneş, 2003, 111)

Emek, doğal kaynak ya da sermaye artık fakir insanların refahın arttıracak temel üretim faktörleri olmaktan uzaklaşmış, üretim süreci içerisinde çalı̧̧anların yaşam kalitesinin arttırllması ve bilginin geliştirilmesi ön plana çıkmıştır. Bu yöndeki geliş̧meler ise ancak insan sermayesine yapılacak yatırımlar sayesinde să̆lanabilecektir.

Entelektüel sermaye ve insan sermayesi benzer kavramlar gibi görünse de birbirlerinden farklı kavramlardır. İnsan sermayesi bulunduğu zaman dilimi içerisinde tek bir alanda yaşama alanı bulurken entelektüel sermaye aynı zaman diliminde birden fazla alanda etkili olabilir. Bu nedenle de insan sermayesi entelektüel sermayenin bir alt dalı olarak karşımıza çıkar. Bu noktada da insan sermayesini entelektüel varlıklara dönüştürebilmek önem taşımaktadır.

\section{IIP Standardı ve Gelişim Süreci}

IIP Standardını insan kaynakları yönetimi uygulamaları temelinde destekleyici bir yaklaşım olarak tanımlayabiliriz. Bu tanım doğrultusunda, insan sermayesinin değerlendirilmesinde ve IIP Standardının uygulanabilirliğinin ölçülmesinde örgüt içerisinde insan kaynakları uygulamalarının hangi oranda gerçekleştirildiği önem taşımaktadır. Bu doğrultuda; insan kaynakları planlaması ile gerekli nitelik ve nicelikte insan kaynağını bulma ve seçme, eğitim ihtiyaç analizleri yapılarak eğitim ve geliştirme programlarının düzenlenmesi, örgütün amaçlarına ulaşması noktasında performans değerlendirmenin yapılması ve çalışanları motive etmede ücretlendirmeyi dört temel insan kaynakları uygulaması olarak ele alabiliriz. Belirlenen bu insan kaynakları uygulamaları IIP Standardı çerçevesinde uyumlaştııılmalıdır.

IIP Standardının örgüt içerisinde insan kaynakları uygulamaları ile paralellik göstermesi hem belirlenen stratejik planların gerçekleştirilmesinde hem de sürekli değişen çevre koşullarına uyum sağlamada önemlidir. Ayrıca IIP Standardının uygulanabilirliğini ölçmedeki en önemli insan kaynakları uygulaması, objektif bir şekilde uygulanan performans değerlendirme sisteminin gerçekleştirilmesine bağlıdır. 
Üst düzey yöneticiler sık sık “en önemli değerimiz insandır” olgusunu savunmaktadırlar. Organizasyonların bu sözü gerçeğe dönüştürmesine yardımcı olan IIP Standardı, Birleşik Krallığın ulusal bir çerçevesidir. IIP Standardı, insan kaynağının gelişimine yönelik çalışmaların ne ölçüde başarılabileceğini gösterebilen niteliktedir ve organizasyonun kendi standartlarını ulusal bir şekilde tanınmış standartlarla karşılaştırmalı olarak değerlendirebilmesini sağlamaktadır. Bu noktada IIP Standardı; organizasyonun amaçlarının gerçekleşmesinde insan kaynağının değerini gözeten, tüm kuruluşların vizyonu olan ve kurumsal başarının gerçekleştirilmesinde etkin rol oynayan bir standardı oluşturmaktadır. Organizasyon amaçlarının gerçekleştirilmesi için çalışanların katkılarının geliştirilmesi, hem çalışanlar ve kuruluş hem de kuruluş dışındaki kişiler için fayda sağlayan bir durumdur. $\mathrm{Bu}$ durum, bireylerin kendi potansiyellerinin farkına varmasına, organizasyonların artan üretim sayesinde daha iyi bir refah düzeyi sağlamasına ve toplumun da daha kaliteli bir hayat standardı yakalamasına yardımcı olmaktadır. (Greener ve Bourner, 2005, 3)

IIP Standardının insan kaynağını geliştirmesinde etkili olacak şekilde organizasyonun bu standardı kullanarak hedefine ulaşmaya karar vermesi durumunda şu süreçleri izlemesi gerekmektedir: (Greener ve Bourner, 2005, 5)

1. Organizasyonun amaçlarını net bir şekilde belirlemesi ve bu amaçların herkes tarafından anlaşıldığından emin olması,

2. Organizasyon içindeki her bireyin ve ekibin kurumun amaçlarını gerçekleştirmede ne kadar katkı sağlayabileceklerinin belirlenmesi ve bu katkıyı nasıl sağlayabileceklerinin planlanması,

3. Harekete geçilerek planın gerçekleştirilmesi,

4. Organizasyonun çalş̧anlarının gelişiminde daha iyi olabilmesi için planın kuruluşun amacını gerçekleştirmede birey üzerindeki etkilerinin değerlendirilmesi.

IIP Standardı akreditasyonu kazanmak için organizasyonlar önce standartları gerçekleştirmeye taahhüt verirler ve daha sonrasında performans öğelerini gösteren bir değerlendirme teslim ederler. IIP Standardı taahhüdünü IIP akreditesine çevirmek büyük ölçüde çalışanların eğitimine yapılacak olan yatırımı gerektirir. IIP akreditasyonunu kazanmış kurumlar IIP logosunu işletme ürünlerinde ve işletmede bulundurabilirler. IIP Standardının her üç yılda bir ya da daha kısa aralıklarla değerlendirilmesi işletme içinde sürekli eğitim desteğini devam ettirmek için gereklidir. (Maxwell ve diğerleri, 2001, 737)

IIP Standardının objektif bir şekilde uygulanmasını sağlamak için yetkili kuruluşlar değerlendiriciler tayin edebilirler. Akredite olmuş değerlendiriciler denetlemeleri müşteri kuruluşlarda gerçekleştirirler. Değerlendiriciler genellikle üst düzey yöneticilerle görüşmeler talep ederler. Bunun yanı sıra, müşteri kuruluşlar içerisindeki çalışanlardan da bir örneklem belirleyip bu kişilerle de görüşmeler yapabilirler. Değerlendiriciler, tecrübeli ya da yeni, tüm bölümlerden ya da birimlerden çalışanlarla ve yöneticilerle görüşmeyi amaçlarlar. Örnek bir çerçeve oluşturmadan önce değerlendiriciler gönüllü çalışanlar ya da kurum içerisinde daha esnek ilişkilere sahip olan çalışanlardan kimlerin değerlendirme sürecine katılması gerektiğine karar verirler. Müșteri kuruluşlar bu standardın gerekliliklerini tam anlamıyla yerine getirdiğinde ve tanındığında, değerlendirici kuruluşa daha mükemmel uygulamalar ve ileride gerçekleştirmeyi planladıkları gelişmeler hakkında geri dönüşler sağlar. IIP akreditasyonu sahibi kurum ve kuruluşlar herhangi bir değerlendirmeye tabi tutulmadan Standart tanınırlığını üç yıl süre ile elinde tutabilir ya da isteğe bağlı olarak yıllık yenilemeler de talep edebilirler. (Greener ve Bourner, 2005, 5-6)

İnsan kaynakları yönetimi açısından İngiltere'de kilometre taşı olarak nitelendirilebilecek IIP Standardı, kurumsal performansın arttırılması için insan gücünün motivasyon ihtiyacına da vurgu yapar. Bu bağlamda çalışanların kuruma aidiyet hissini arttırma ve kurum için verimli bir şekilde çalışmanın kendi kariyerleri adına yatırım (değer arttırıcı) niteliğinde olduğunu çalş̧anlara benimsetme amacı güden düşünsel bir altyapıya sahiptir. Birleşik Krallıktaki birçok uygulamacı IIP Standardını, en iyi uygulamalar bütünü şeklinde tanımlamaktadır. IIP Standardının öngördüğü şartlar genellikle iş planıyla uyum içinde olup planlı bir bütün niteliğindedir. IIP Standardına verilen taahhüt, aynı zamanda bir işletme için insan kaynakları yönetimi hususunda bir taahhüt niteliği taşımaktadır. Standardın öngördüğü şartlar, genellikle insan kaynakları bölümündeki stratejik amaçlarla uyum içinde tasarlanmıştır. Yine de bazı kurum içi eğitimciler bu yaklaşımı sorgulayıp çalışanların eğitiminin daha doğal bir süreç içerisinde olması gerektiğini savunmaktadırlar. (Kidger, Jackson-van Veen ve Redfern, 2004, 506) Bu bağlamda IIP Standardı özellikle gelişmekte olan kuruluşlarda insan kaynakları faaliyetlerini uyumlaştırmada önemli bir rol oynamaktadır. Bu yönü ile IIP Standardı, uzun vadede geleceğe yönelik olarak insana yapılan yatırımı destekleyen ve taahhüt veren bir insan kaynakları politikası niteliğini taşımaktadır. (Bourne ve diğerleri, 2008, 21) 




Şekil 2: IIP Standardının Gelişimi

Kaynak: Gloster ve diğerleri, 2010:24

IIP standardının gelişimi Şekil 2'de görüldüğü üzere ihtiyaçlara paralel olarak zaman içinde çeşitli değişikliklere uğramıştır. Standartta yapılan ilk değişiklik 2000 yılında daha sade bir dilin kullanılması ve performans vurgusunun arttırılması doğrultusunda gerçekleştirilmiştir. Yapılan bu değişiklik standardın sonuç odaklılığını arttırmış, geçmiş uygulamalara göre kuralcılığını azaltmıştır. Yine Standart 2002 yılında daha esnek bir hale getirilmiş ve "Profil Aracı" (Profile Tool) aracı yayınlanmıştır. Profil Aracı üç temel göstergeden oluşturulmuştur. Bunlar; 'Stratejinin Geliştirilmesi', 'Stratejinin Uygulanması' ve 'İnsanın Geliştirilmesi' olarak belirlenmiştir. Standardın güncellenmiş şekli 2004 yılında yayınlanmış sürekli gelişimin sağlanmasına yönelik 'Planla-Uygula-Kontrol Et' yapısı, çerçeveye temel teşkil eden 10 gösterge ile birleştirilmiştir. Standardın bu yeni şekli özellikle liderlik, yönetim stratejisi ve yönetimin etkinliğine yönelik kriterler açısından daha esnek bir yapıya sahiptir. Profil Aracının yeni şekli (2004) kapsamın genişliği ve derinliği açısından örgütsel değerler, deneme ve seçme, iş hayatı dengesi, sosyal sorumluluk, mentor ve özendirici liderlik konularında ek gereklilikler içermektedir. (Gloster ve diğerleri, 2010, 3)

IIP Standardı 2009 yılında "Yeni Seçenekler Yaklaşımı" ile işverenler açısından daha esnek bir hale gelmiştir. Bu yaklaşım ile liderlik ve yönetim niteliklerine vurgu yapılmış ve kurumlara kendi öncelikli amaçları doğrultusunda belirledikleri kriterler üzerinde yoğunlaşma imkânı tanınarak standart bir çekirdek yapının üzerinden en iyi sonucu elde etmeye yönelik işletme amaçlarının desteklenmesi sağlanmıştır. Bu durum da bronz, gümüş ve altın dereceleriyle akreditasyonun sınıflandırılmasını sağlamıştır. Ayrıca Nisan 2010'da IIP Standardının stratejik sahipliği ve çerçevesi IIP UK'den UK Commission'a devredilmiş ve böylelikle IIP Standardının gelişiminden, politikalarından, stratejik yöneliminden, lisanslama, ödüllendirme ve akreditasyon işlemlerinden sorumlu kuruluş "UK Commission for Employment and Skills" olmuştur. (Gloster ve diğerleri, 2011, 1)

Organizasyonların eğitim ve geliştirme faaliyetlerini arttırmak için tasarlanan hükümet destekli IIP Standard1, kurum içerisinde eğitim kültürünü geliştirmeye odaklanan kültür odaklı yeni bir standardı benimsemiştir. Standarttaki bu değişiklik, kurum kültürü üzerinde açık bir ilgi geliştirildiğini göstermiş ve bu konuda birçok tavsiye bulunulmasına rağmen bu sürecin dinamikleri yeterince irdelenememiştir. (Collins ve Smith, 2004, 583-584) Bu durum IIP Standardını özellikle kurum kültürü açısından ele almayı gerekli kılmıştır. Kültür odaklı bu yaklaşım ile birlikte IIP Standardı uygulaması sürecini anlayabilmek için kültürü yorumlayıcı bir bakış açısı temel alınmıştır. Bu bağlamda, organizasyon başlı başına ayrı bir kültürdür ve kurumsal kültür kurumdaki çalışanlar tarafından oluşturulan ve çalışanların üzerinde önemli bir etkiye sahip olan bir olgudur. (Parker, 2000)

Standarttaki bu değişiklik aynı zamanda akredite olmuş kurumların kurumsal kültürü oturtabilmek adına nasıl başarıyı yakaladıklarından ziyade bu Standart sayesinde neyi ne kadar başarabildikleri konusunda sorgulanmalarını gerektirmektedir. Bu yeni standart, esnek görünmesine rağmen açıkça belirtilmemiş olsa da prosedürlerin resmileştirilmesini ve tanımlanmasını öngörmektedir. Bu çerçevede kurumun standardını kendi kültürüne ve diline göre yorumlamasına izin vermemektedir. (Grugulis ve Bevitt, 2002) Bu yüzden de kurumlar IIP Standardının başarıya ulaşması noktasında kurum kültürünün standarda duyarlı olması önemlidir.

IIP Standardı reçete gibi prosedürler önermese de standardın temel amacı sürekli gelişmeyi sağlamaktır ve bu amaç kurumlarda halen uygulanmaktadır. Burada asıl önemli konu, standardın gerçekten değişip değişmediği ve standart değiştiyse de bu değişikliğin kurumlar ve danışmanlar tarafından etkili bir şekilde nasıl destekleneceğidir. Aynen standardın eski formunda olduğu gibi yeni standart da taahhüt, planlama, uygulama ve değerlendirme olmak üzere dört ana ilke üzerine kuruludur, ancak bu ilkeler tekrar yazılarak daha kültür odaklı hale getirilmiştir. Eski ve yeni standart arasındaki temel fark, yeni standartta daha az şartın bulunması ve 
bunların yapılan faaliyetlerden ziyade çalışanlar ve yönetimin inançları ve bakış açıları gibi kültürel ögelere bağlı kanıtlarla desteklenmesidir. (Collins ve Smith, 2004, 588)

IIP Standardının 2000 yılında uğramış olduğu revizyon sonrası durumu ile revizyon öncesi durumunun karşılaştırılması Tablo 1'de yer almaktadır. Revize edilmiş standart, anlaşılabilir sade bir dilin kullanımı ve kurumun standarda adaptasyon sürecinin kolaylaştırılması esasına dayanmaktadır.

Tablo 1: IIP Standardının Revize Öncesi ve Sonrası Durumunun Karşılaştırılması

\begin{tabular}{|c|c|}
\hline $\begin{array}{l}\text { Eski Standart } \\
\text { (Uygulama Odaklı) }\end{array}$ & $\begin{array}{l}\text { Yeni Standart } \\
\text { (Kültür Odaklı) }\end{array}$ \\
\hline Taahhüt & \\
\hline $\begin{array}{l}\text { Yönetim tarafindan işin amaçların gerçekleştimek } \\
\text { ve tüm çalışanların gelişimini sağlamak için taahhǜt } \\
\text { verilmesi. }\end{array}$ & $\begin{array}{l}\text { Kunumun amaçlarını ve planların gerçekleştimek } \\
\text { için örgüt ortammı gözetecek şekilde taahhüt } \\
\text { verilmesi. }\end{array}$ \\
\hline $\begin{array}{l}\text { Planlama } \\
\text { Çalışanlarm eğitim ve gelişim ihtiyaçlarının ve } \\
\text { planlarının düzenli aralıklarla gözden geçinimesi. }\end{array}$ & $\begin{array}{l}\text { Kültürel açıdan amaçlar hakkmda ve çalışanların bu } \\
\text { amaçları başammak için neler yapması gerektiğini } \\
\text { açıkça belirtmek. }\end{array}$ \\
\hline Uygulama & \\
\hline $\begin{array}{l}\text { Bireylerin işe alımları ve çalışma süreçlerinde eğitim } \\
\text { ve gelişimlen için harekete geçmek. }\end{array}$ & $\begin{array}{l}\text { Performansını geliştimek için çalışanları etkili bir } \\
\text { şekilde geliştimmek. }\end{array}$ \\
\hline Değerlendirme & \\
\hline $\begin{array}{l}\text { Başarıyı değerlendimek ve gelecekteki etkinliği } \\
\text { arttumak için eğitim ve gelişime yapılan yaturım } \\
\text { değerlendime. }\end{array}$ & $\begin{array}{l}\text { Yatırmin insanlar üzeninde etkisini kurum kültünü } \\
\text { çerçevesinde anlamak. }\end{array}$ \\
\hline
\end{tabular}

Kaynak: Collins ve Smith,2004:588

Ek'te yer alan IIP Standardı çerçevesine göre; IIP Standardı, 3 temel prensip, bu prensiplere bağlı 10 temel gösterge ve bu göstergelerin dayanağı olan toplam 39 kriterden meydana gelmektedir. Bir kurumun IIP akreditasyonu edinmesi temel prensipler çerçevesinde yerine getirebildiği göstergeler üzerinden değerlendirilmektedir.

IIP Standardını edinme süreci içerisinde organizasyon bu standardı kullanarak hedeflerine ulaşmaya karar verdiğinde bu 10 göstergeyi de dikkate alarak sürekli bir değerlendirme süreci izlemesi gerekmektedir. Bu süreç içerisinde ise şu faaliyetler yürütülmektedir: (Greener ve Bourner, 2005, 5)

1. IIP Standardı göstergelerini sağlamak için kriterler üzerinde yapılacak tanısal bir test gerçekleştirilebilir. Test sonucu değerlendirme IIP Standardı tarafindan akredite olmuş bir değerlendirici eşliğinde yapılacak bir iç değerlendirme ya da resmi bir değerlendirme olabilir. Değerlendirme sonunda nadiren de olsa organizasyonun hali hazırda IIP Standartlarını karşıladığı da görülebilir.

2. Eğer bazı şartlar en başta organizasyonda mevcutsa bu şartların kalıcı, geçerli ve güvenilir olarak kalması kaydıyla son aşama değerlendirmesi için bu durum referans olarak baz alınabilir. Organizasyonun karşılayamadığı şartlar için faaliyetler IIP Standardının öngördüğü 10 göstergeye göre planlanir.

3. Organizasyonun faaliyetleri bu 10 göstergeyi karşılamak amacıyla gerçekleştirilir.

4. IIP Standardında yer alan 10 göstergenin resmi ve sürekli olarak değerlendirilmesi gerekir. Bu değerlendirme, çalışanlarla görüşebilecek, kuruluşu gezebilecek, kuruluş içi toplantılara katılabilecek, planlama ve çalışanların gelişmesiyle ilgili evraklara bakabilecek bir değerlendiricinin ziyaretini içerir.

Eğer organizasyon, bu göstergelerden birini ya da daha fazlasını karşılayamıyor ise kuruluşun bu konudaki faaliyetlerini yeniden düzenlemesi ve bunun sonucunda hazır olduğunda tekrar denetlenmesi gerekmektedir. Çünkü IIP akreditasyonu tek seferlik gerçekleştirilen bir olgu değildir. Bu noktada IIP Standardı belirli aralıklarla geri dönüşler yapılıp organizasyonun performans düzeyi de göz önünde tutularak gösterge ve göstergelerden yola çıkılarak kriterlere dayalı sürekli bir sistemi gerektirmektedir.

\section{Geçmişte Yapılan Araştırmalara İliş̧kin Bulgular}

IIP Standardı üzerine yabancı literatürde özellikle Birleşik Krallık ülkelerinde yapılmış çok sayıda araştırma bulunmaktadır. Elde edilen sonuçların farklılıklar gösterdiği çalışmaların bazılarına bu bölümde yer verilmiştir. Spilsbury ve diğerleri (1995), İngiltere ve Galler'de farklı sektörlerden IIP Standartlarını uygulayan 1136 firma üzerinde anket yöntemiyle yaptıkları araştırmada; söz konusu firmaların üçte ikisinin eğitim uygulamalarında değişikliğe gittiği ve işverenlerin \% 90 oranında bu değişikliği standarda dâhil olmanın bir sonucu olduğuna 
inandıklarını tespit etmişledir. İşverenlerin \% 57'lik kısmı IIP Standartlarının çalışan niteliğinin gelişimine katkı sağladığını ifade etmişlerdir. Ayrıca yine işverenlerin üçte ikisi, çalışan niteliğindeki gelişimin finansal olmayan kurumsal performansı arttırdığı ve geleceğe yönelik olası katkılarının da olabileceğini ifade etmişlerdir. Hillage ve Moralee (1996), Birleşik Krallık ülkelerinde farklı endüstrilerde faaliyet gösteren işletmeler üzerinde yaptıkları araştırmada; IIP Standartlarının uygulandığı işletmelerin \% 42'sinin verimlilik artışı sağladığını ve finansal performansının artış gösterdiğini bulmuşlardır. O'Neill (1996), Kuzey İrlanda'da turizm sektöründe hizmet veren işletmeler üzerinde yaptı̆̆ı çalışmada; standardı uygulamanın eğitim yetersizliğinden kaynaklanan sorunların giderilmesinde ve finansal olmayan performans üzerinde olumlu bir etkisi olduğunu tespit etmiştir. Alberga, Tyson ve Parsons (1997), Birleşik Krallık ülkelerinde faaliyet gösteren 455 işletme üzerinde anket ve mülakat yöntemiyle yaptıkları araştırmada (ankete katılım oranı: \% 57); IIP Standardının finansal ve finansal olmayan kurumsal performansı olumlu yönde etkilediğini ve standardı sağlama sürecinde işverenlerin insan kaynaklarının gelişimine önem gösterdiğini tespit etmişlerdir. Hogg, Carter ve Dunne (1998), İngiltere'de imalat sektöründe faaliyet gösteren ve IIP Standartlarını uygulayan bir firmada 236 katılımcıdan \% 87,4 oranında geri bildirim aldıkları anket ve görüşmeler sonucu; pazarlama stratejisi çerçevesinin oluşturulmasına ve örgüt kültürünün gelişmesine katkı sağladığını bulmuşlardır.

Smith (2000) yaptı̆̆ araştırmada; İngiltere'de faaliyet gösteren bir kamu hastanesini incelemiştir. Yaptığ görüşmeler sonucunda; (NHS Trust Hospital) hastanenin işletme stratejisine uyumluluğunun arttığını ve kurumsal amaçlar doğrultusunda çalışanların örgüt kültürü konusunda gelişimim gösterdiğini tespit etmiștir. Bell, Taylor ve Thorpe (2001), İngiltere'de farklı sektörlerde faaliyet gösteren 60 ile 2000 kişi aralığında değişen çalışanı bulunan 6 firma üzerinde yaptıkları araştırmada; IIP Standardının finansal olmayan performans üzerinde olumlu etkisi olduğunu tespit etmişler ve aynı zamanda insan kaynakları yöneticileri tarafindan kariyer geliştirme yöntemi olarak kullanıldığı ve insan kaynakları departmanının itibarını artırdığı, kurum içindeki yerini sağlamlaştırdığı, standardı uygulamanın ve faydalı sonuçlar elde etmenin sosyo-politik süreçlerin etkisi altında olduğunu sonucuna ulaşmışlardır. Yine Bell, Taylor ve Thorpe (2002a), aynı kurumlar üzerinde yaptıkları ikinci araştırmalarında; 77 kişiyle görüşmüş ve IIP Standardının marka farkındalığı yaratmada bir araç olarak görüldüğünü ve bazı büyük firmaların kurumsal saygınlık açısından standardı uyguladıklarını tespit etmişlerdir. Ancak IIP Standardı sertifikası alan firma sayısının artmasının bu sertifikaya sahip olmaktan dolayı bir saygınlık kazandırmayacağını düşünenlerin de olduğunu ve sertifikaya sahip bazı firmaların sertifikayı muhafaza açısından motivasyonlarının azalabileceğini de belirtmiş̧tir. Yetkili kurum IIP UK'nin bu durumun önüne geçmek için iki seçeneği olduğunu ve bunların derecelendirme (gradation) ve uzmanlaşma (specialization) olduğunu çalışmalarında ifade etmişlerdir. Smith ve diğerleri (2002), İngiltere'de farklı endüstrilerden KOBí niteliğinde 591 işletme üzerinde yaptıkları araştırmada; IIP Standartlarını uygulamanın sonucu olarak ortaya çıkan başlıca iki faydayı, stratejik planlarla çalışan niteliğinin gelişimi arasında bağlantının kurulmasını sağlaması (\% 81) ve eğitim faaliyetlerinin işletme ihtiyaçlarına odaklanması (\% 79) olarak tespit etmişlerdir. Bu iki fayda IIP Standardının rekabet üstünlüğü sağlanması amacına yönelik temellerine işaret etmektedir. Ayrıca standardın sağladığı diğer faydaları; eğitim verimliliği, motivasyon ve performans değerlendirmesi olarak belirtmişlerdir. Smith ve diğerleri araştırma kapsamında görüş̧ükleri katılımcıların IIP Standartlarından yararlanmanın finansal performansın artması açısından fayda sağladığını belirtmenin zor olduğunu bildirdiklerini de belirtmişlerdir. Michaelis ve McGuire (2004), Birleşik Krallık'ta farklı sektörlerde faaliyet gösteren ve IIP Standardı uygulayan 1600 firma üzerinde telefon görüşmeleri yapmışlar; finansal açıdan kurumsal performansın olumlu etkilendiği sonucuna ulaşmışlardır. Ortalama olarak satışlar üzerinden \% 7,6 karlarda artış ya da çalışan başına £505 satış gerçekleştirirken diğer firmalarda bu oranın \% 3,78 ve çalışan başına satış tutarının $£ 197$ olduğu tespit etmişlerdir. Bu farklılık standardı uygulamanın bir sonucu olarak değerlendirilebilmektedir. Firma ölçeği bazında sınıflandırma yapıldığında küçük firmalarda çalışan başına £303, orta ölçekli firmalarda çalışan başına $£ 602$ ve büyük ölçekli firmalarda çalışan başına $£ 41$ olmuştur. Bu verilerin düzenlenmesinden yola çıkarak yaklaşık $£ 756$ milyon tutarındaki karın standardın uygulanmasından kaynaklanabileceğini ve sonuç olarak firmaların net \%94 oranında IIP Standardını uygulamasının sürekliliğinin firmalara değer sağladığı tahmin edilmiştir.

Literatürde IIP Standardı uygulamasının firmanın finansal olmayan performansı üzerinde olumsuz sonuçlar doğurabileceğini gösteren çalışmalar da mevcuttur.

Hill ve Stewart (1999), Kuzey Batı İngiltere'de farklı sektörlerde faaliyet gösteren 68 firma üzerinde anket (katılım oranı: \%19,4) ve görüşme (görüş̧e sayısı: 23) yöntemi kullanarak bir araştırma yapmışlardır. KOBİ niteliğindeki bu firmalarda standardın zaman ve para kaynağı açısından, formalite ve bürokrasi açısından gereksiz olduğu, elde edilecek sonuçların belirsiz olduğu gibi konular üzerinden kabul görmediği sonucuna ulaşmışlardır. Watson ve Watson (1999) yaptıkları araştırmada; Birleşik Krallık'ta iki üniversite üzerinde incelemelerde bulunmuşlar ve IIP Standardına uyum sağlamanın bu kurumlar açısından bazı potansiyel sakıncalar içerdiğini (örneğin performans değerlendirme) tespit etmişlerdir. Grugulis ve Bevitt (2002), Kuzey Batı İngiltere'de bir kamu kuruluşunda anket ve görüşme yöntemiyle yaptıkları çalışmalarında; 124 çalışana anket uygulamışlar (katılım oranı: \% 45) ve 30 çalışan ile de görüşmüşlerdir. Araştırmaya göre standardın çalışan niteliği ve yeteneğinin arttırılması için gerekli olmadığı, çalışanların motivasyon anlamında güvenilir ve 
iyi yönetimi önemsediklerini ve bazı kurum içi uygulamaları anlamsız bulduklarını tespit etmişlerdir. IIP Standardının formal yapıda olduğunu ve esnek bir mekanizma olarak görülmediği sonucuna ulaşmışlardır. Ayrıca Fraser (2003), IIP Standardının büyüme üzerindeki etkisini araştırmış ve bu konuda çalışma yapan başkaları da (Berry ve Grieves, (2003); Down ve Smith, (1998)) IIP Standardının kurumun performansı üzerindeki etkilerini araştırmışlardır. Bu çalışmalara göre, IIP Standardının sadece bazı durumlarda ve bazı kuruluşlarda pozitif bir etkiye sahip olduğunu savunmuşlardır.

Ayrıca IIP Standardının olumsuz sonuçlar verdiği bazı çalışmalar da şu durumlara vurgu yapmaktadır: (Bourne ve diğerleri, 2008, 16)

1. IIP Standardını elde etmek bazı kurumlar ve özellikle KOBİ'ler için aşırı derece resmiyet ve bürokrasi gerektirdiğinden zaman israfına sebep olabilecek bir faaliyettir (Grugulis ve Bevitt, 2002; Hill ve Stewart, 1999; Ram, 2000), ancak bu çalışma yapıldığından beri IIP Standardı güncellenmektedir.

2. IIP Standardı özellikle üniversiteler gibi kurumlarda kurumun işleyişi dışında prosedürler gerektirdiğinden kısa vadede performansı düşürüp eleştirilere ve tartışmalara yol açabilir. (Watson ve Watson, 1999)

3. IIP Standardının temel kazanımlarından biri olmamasına rağmen insan kaynakları yöneticilerinin kariyer gelişimi açısından bir araç olarak kullanılabilir. (Bell, Taylor ve Thorpe, 2001)

4. İş ortamının daha yumuşak ve süreç odaklı öğrenme çerçevesiyle, IIP Standardı sürecinin daha zor ve içerik odaklı öğrenme çerçevesiyle çakıştığı için IIP Standardı kurumsal öğrenmeyi engelleyebilir. (Bell, Taylor ve Thorpe, 2002b)

Sonuç olarak, çalışmaların çoğunun IIP Standardının olumlu etkisi olduğunu ve kuruma değer kattığını göstermesine rağmen çalışmaların sonuçları bunu kesin olarak kanıtlayamamaktadır. Geri dönüşler göz önüne alındığında IIP Standardının resmi olarak uygulanması sonucu kurumlarda pozitif bir etkiye sahip olduğu, strateji ve politika değiş̧ikliklerine bağlı olarak güçlü bir liderlik oluşturduğuna dair çalışmalar mevcuttur. Fakat aynı zamanda, IIP Standardının etkisine katkı sağlayan bazı muhtemel faktörlerin olduğu da aşikardır. Bu faktörler; kurumun büyüklüğü, endüstri, performans ve insan kaynakları faaliyetleri üzerine yapılan ön çalışmalardır. Çıkarılan bu sonuçlara göre işletmenin türüne, büyüklüğüne ve uygulanma şekline göre IIP Standardının sonuçları değişebilmektedir. (Bourne ve diğerleri, 2008, 17)

IIP Standard, örgüt içerisinde çalışan personelin performansının insan kaynakları uygulamaları çerçevesinde objektif bir şekilde ölçümlenerek kurum kültürüne uygun bir platformda tüm örgüte yayılan yüksek bir kurumsal performans düzeyi yakalayabilmeyi örgüte sunmaktadır. Bu şekilde günümüz küresel rekabet ortamında ayakta kalabilmek kolaylaşırken aynı zamanda çalışanların motivasyon düzeyleri artırılarak iş tatminiyle birlikte işe ilişkin verimlilik ve etkinlik düzeyleri maksimum seviyeye çıkarılmaya çalışılır. 2000'li yıllarda Türkiye'de birkaç firmanın akredite edilmiş olmasına rağmen (Örneğin; Garanti Bankası, Akenerji) IIP Standardına ilişkin ve standardın faydalı olup olmadığının test edilmesine ilişkin bilimsel literatürün bir hayli kısıtlı olduğunu söyleyebiliriz.

\section{IIP Standardının Kurumsal Performans Üzerindeki Stratejik Etkileri}

IIP Standart ve göstergeleri, çalışanların amaçları ve insan kaynakları uygulamaları ile bütünleştiği zaman organizasyonun performansını daha çok artıran bir etki yaratabilmektedir. İnsan kaynakları politika ve uygulamalarının birbirleriyle uyumlu olması işletmeler açısından etkili bir sinerji oluşturur. Stratejiler ve stratejik insan kaynakları yönetimi de politika ve uygulamalar ile bütünleştirilmelidir. Aynı zamanda insan kaynakları politika ve uygulamaları ile IIP Standardı bir bütünlük oluşturmalıdır.

Stratejik yönetim, bir işletmenin uzun dönemde varlığını devam ettirebilmek, ona sürdürülebilir bir rekabet üstünlüğü sağlamak ve dolayısıyla uzun dönemde performansını sürekli iyileştirebilmek amacıyla, eldeki üretim kaynaklarının etkili ve verimli olarak kullanılması şeklinde ifade edilmektedir. (Bingöl, 2013, 8) Bu noktada IIP Standardı işletmenin stratejik nitelikteki amaçlarını gerçekleştirebilmesi açısından pozitif bir etkiye sahiptir. Yani IIP Standardı ile birlikte stratejik yönetim performans yönetimi ile bağdaştııılmış ve insan kaynakları stratejisi ile işletme stratejisi arasındaki denge standardın getirdiği performans sistemi ile sağlanmıştır. $\mathrm{Bu}$ nedenle stratejik amaç ve hedeflerin gerçekleştirilmesinde insan kaynaklarının doğru ve etkin bir şekilde kullanılması ve IIP Standardının bu sürece etkisi önemlidir.

Stratejik insan kaynakları yönetimi çerçevesinde kurumsal performansın artırılmasını sağlayacak şekilde IIP Standart göstergeleri ve kriterlerinin belirlenerek organizasyon içerisinde hem çalışanlarla hem de kurumla bir bütünlük oluşturularak gerekli sinerji yaratılmalıdır. IIP Standardının performansa olan katkısının önemli bir ölçüm yolu işletmeye ilişkin finansal performans düzeyinin finansal olmayan varlıkların da yer aldığı mali tabloların incelenmesidir. 
Bourne ve diğerleri (2008), geçmişte yapılmış çalışmaların sonuçlarından yararlanarak yaptıkları araştırmada; literatürdeki çelişkili sonuçların nedenleri üzerine eğilerek IIP Standardının kurumsal performans ile olan ilişkisini ortaya koyabilmek adına bir "öneri çerçeve" çizmişlerdir. Bu çerçeveye göre IIP Standardı kurumsal performansın finansal olmayan göstergelerini doğrudan ve dolaylı olarak etkilemektedir. Buradaki dolaylı etki IIP Standardının insan kaynakları politikası üzerindeki etkisinden yola çıkarak kurumsal sosyal iklim ve beşeri sermayenin esnekliğini etkilemekte, sonuç olarak da finansal olmayan performans üzerinden geri bildirim sağlanmaktadır. Söz konusu “öneri çerçeve” Şekil 3'de yer almaktadır.

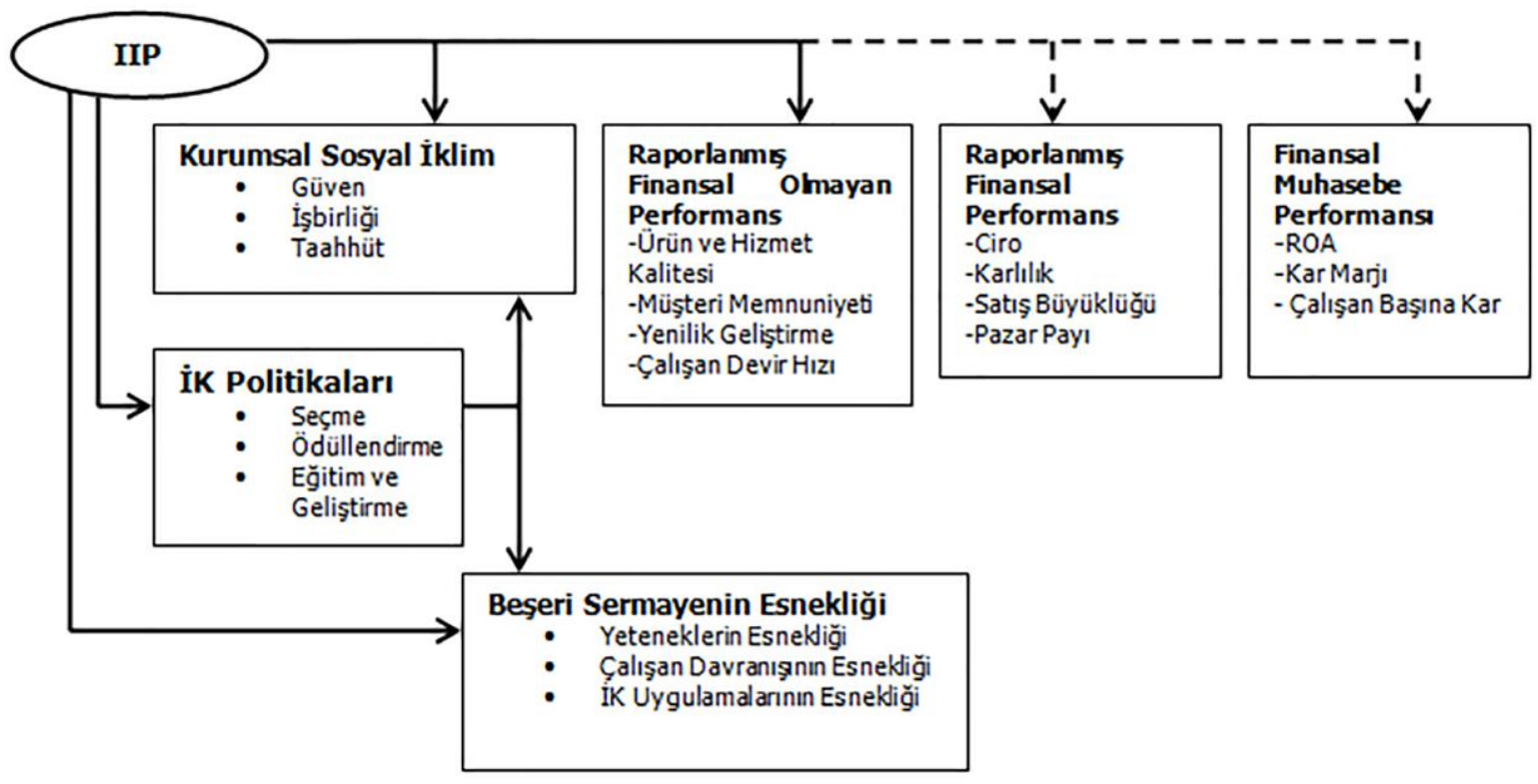

Şekil 3. IIP Standardı ve Kunumsal Performans İlişkisi, Öneni Çerçeve

Kaynak: Boume ve diğerleri, 200s:24

Bourne ve diğerlerinin yapmış oldukları çalışma çerçevesinde, IIP standardına uyum sağlamanın daha iyi bir finansal performansla sonuçlanan etkiye sahip olduğu görülmektedir. IIP Standardına uyum sağlayan organizasyon, aynı zamanda insan kaynakları politikalarını da IIP Standardına göre belirleyecektir. Politikalardaki bu değişikliklerle birlikte organizasyon içerisinde iki yön üzerinde büyük bir etki oluşmaktadır. İlk olarak, insan kaynakları politikaları kuruluşta pozitif bir kurumsal sosyal iklim yaratır. Sonrasında, insan kaynakları politikaları, kuruluşun değişmesi için gerekli beceri ve davranışları içeren beşeri sermaye esnekliğini artırır. Beşeri sermaye esnekliğinde ve kurumsal sosyal iklimdeki değişiklikler finansal olmayan performans üzerinde etkiye sahiptir. Finansal olmayan alanlarda iyi bir performansa sahip olan kuruluşların finansal performans bakımından da iyi bir sonuca ulaştığı ve yıllık basılan raporlarda organizasyonun değerlerine ilişkin finansal açıdan da etkiye sahip olduğu izlenmektedir. (Bourne ve diğerleri, 2008, 5)

IIP Standardı özellikle Performans Gelişim Planlaması (PDP) amacının vurgulanması üzerine geliştirilmiş bir yöntem niteliğindedir. Yöneticilerin hali hazırda bu konuda kendi eleştirileri ve geri dönüşleri mevcuttur. Asıl gerekli olan şey ise, istenen sonuçların elde edilmesi ve kurumun amaçlarının gerçekleştirilmesi için bu durumları paylaşmada daha geniş bir kitleye hitap eden bir paylaşım metodunun bulunması durumudur. Bu yeni sistem yöneticilerin çalışanlara kurum amaçlarını tanıtabilecek ve bunu başarmaya yönlendirecek bir beceriye sahip olmasına dayanmaktadır. Bu süreç IIP Standardının temel öğesidir. Tüm yöneticilerin ve çalışanların Performans Gelişim Planlaması tanıtılmadan önce bir farkındalık eğitimi almaları önem arz etmektedir. (Mason, 1994, 10) Bu sayede organizasyon içerisinde performans yönetiminin uygulanması ile ilgili olarak çalışanlar bilinçli bir şekilde eğitilerek stratejik nitelikte belirlenen planlara ulaşmak çok daha rahat olacaktır. Bunun sonucunda IIP Standardı, Performans Gelişim Planlaması üzerinde pozitif yönde bir etki yaratabilecektir.

Nasıl ki stratejik yönetim gelecek odaklı ve uzun dönemli stratejik amaçları içeriyorsa IIP Standardı da gelecek odaklı bir şekilde kurumsal kültüre bağlı olarak güncelleştirmeleri içerir. Bu noktada IIP Standardının performansın artırılmasında kullanılması durumunda kurumsal stratejileri uygulamak için örgüt yapısının ve kültürünün stratejiye uygun olması, çalışanların da belirlenen bu stratejileri benimsemesi gerekir. Ayrıca değişen çevre koşullarına uyum sağlamada esneklik önemli bir etkendir ve esneklik de stratejik insan kaynakları yönetimi ile yakından ilişkilidir. IIP Standardının uygulanması da organizasyon içerisinde esneklik koşullarının oluşturulmasına bağlıdır. Organizasyonel esneklik rekabet edilebilirlikte önemli bir etken olması sebebiyle IIP Standardını benimseyen işletmeler açısından esnekliğe uygun nitelikte stratejiler geliştirilmelidir. 


\section{Değerlendirme ve Sonuç}

İnsan sermayesi üzerinde firma sahipliği kurulması mümkün olmadığından insan sermayesine bağlı olarak ortaya çıkan yenilikler firmanın üzerinde hak iddia edebileceği entelektüel varlıklar haline getirilmelidir. Bu nedenle firmaların insan kaynakları yönetimi, bu perspektife sahip nitelikli yöneticiler tarafından belirlenen strateji ve politikalarla şekillendirilmeli ve entelektüel sermayeyi yönetme görevini üstlenmelidir. Çünkü değişen çevre koşullarına uyum sağlayabilme ve değişimi yakalayabilme noktasında taklit edilemez nitelikte olan insan sermayesi, entelektüel varlıkların en önemli unsurlarından birini teşkil etmektedir.

21. yy. bilgi ekonomisinin dinamikleri firmaların entelektüel sermayesinin başlıca unsuru olan insanın önemini daha da arttırmış, bu durum da insan sermayesinin yetenek ve niteliğinin gelişiminin sürekliliğini rekabet edebilirlik adına zorunlu kılmıştır. IIP Standardı insan unsurunu, kurumsal hedeflerin gerçekleştirilmesi için odak noktasına koyması nedeniyle bilgi ekonomisine adaptasyon açısından bir kurumsal yönetim aracı olarak düşünülmelidir.

IIP Standardının uygulama sürecinin etkin ve verimli bir şekilde gerçekleştirilip değişen şartlara uyum sağlayarak geliştirilmesinde ve örgütlerin her seferinde IIP Standardını sağlayabilmeleri açısından üst yönetimin sürekli desteği önem taşımaktadır. Çünkü IIP Standardı bir kere alınmakla tamamlanan bir süreç değildir; organizasyonel esneklik çerçevesinde sürekli olarak kendini yenileyen bir süreçtir. IIP Standardının kendini yenileme noktasında işletmeler açısından esas önem verilmesi gereken nokta ise sürekli eğitim ve geliştirme faaliyetlerinin uygulanarak öğrenen organizasyon boyutuna ulaşılmasını sağlamaktır.

Örgütte insan kaynaklarına yapılan yatırımın geri dönüşümünün ölçümünün en iyi yolu olarak IIP Standardında yer alan gösterge ve kriterler neticesinde elde edilen sonuçlar önemli bir yer teşkil etmektedir. Bu yüzden IIP Standardını uygulayabilen örgütlerde sürekli olarak geribildirim işlemlerinin yapılması, bu sürecin yenilenerek işleyişini ve güncel kalmasını kolaylaştırıcı bir etki yaratacaktır.

Stratejik insan kaynakları yönetimi çerçevesinde performansı ele alırsak IIP Standardı ile işletme performansı arasında her zaman pozitif yönlü bir ilişki olmayabilir. Bu durum işletmelerin büyüklügüne, faaliyet konusuna ve IIP Standardını uygulama şekline göre değişiklik gösterebilir. IIP Standart gösterge ve kriterlerini kabul eden işletmeler açısından Standardı, organizasyonun stratejik planlarına uygun bir şekilde yönetebilmek performansı artırma noktasında süreç içerisinde önemli bir yer teşkil etmektedir.

Organizasyon bünyesinde yer alan insan kaynakları politikaları, örgütsel iklim ve kurumsal esnekliğin IIP Standardı gösterge ve kriterleri ile bütünleştirilmeleri yüksek bir performans düzeyinin sağlanabilmesi açısından önem teşkil etmektedir. Yani işletme içerisinde sadece IIP Standartlarının uygulamaya konulması tek başına bir anlam ifade etmemektedir; önemli olan kurum içerisinde bütünlük sağlayarak tüm örgüte yayılan bir süreç haline dönüştürebilmektir. Özellikle de üst yönetimin desteği sağlanarak bu süreç tüm örgüt içerisinde çok daha etkin bir şekilde işleyebilmektedir. 


\section{KAYNAKÇA}

Alberga, Trixy, Shaun Tyson, ve David Parsons. 1997. "An Evaluation of the Investors in People Standard." Human Resources Management Journal 7:47-60. doi:10.1111/j.1748-8583.1997.tb00281.x.

Bell, Emma, Scott Taylor, ve Richard Thorpe. 2001. "Investors in People and the Standardization of Professional Knowledge in Personnel Management." Management Learning June 2001 32:201-219. doi:10.1177/1350507601322003.

Bell, Emma, Scott Taylor, ve Richard Thorpe (a). 2002. "Organizational Differentiation Through Badging: Investors in People and the Value of the Sign.” The Journal of Management Studies 39:1071-1085. doi:10.1111/1467-6486.00324.

Bell, Emma, Scott Taylor, ve Richard Thorpe (b). 2002. "A Step in the Right Direction? Investors in People and the Learning Organization.” British Journal of Management 13:161-171. doi:10.1111/1467-8551.00229.

Berry, Carolyn ve Jim Grieves. 2003 "To Change the Way We Do Things Is More Important Than the Certificate on the Wall: Does Investors in People Represent an Effective Intervention Strategy for Organisational Learning?", The Learning Organization 10:294-304. doi:10.1108/09696470310486647.

Bingöl, Dursun. 2013. İnsan Kaynakları Yönetimi. İstanbul: Beta Yayınları.

Bourne, Mike, Monica Franco Santos, Andrey Pavlov, Lorenzo Lucianetti, Veronica Martinez, ve Matteo Mura. 2008. The Impact of Investors in People on People Management Practices and Firm Performance. Cranfield School of Management Centre for Business Performance.

Çetin, Ayten. 2005. "Entelektüel Sermaye ve Ölçülmesi.” Marmara Üniversitesi İ.İ.B.F Dergisi Cilt XX, Say1: 1, 359-378.

Collins, Lorna A. ve Alison J. Smith. 2004. "Understanding the new Investors in People standard - lessons from experience.” Personnel Review 33:583-604. doi:10.1108/00483480410550170.

Down, Simon ve David Smith. 1998. "It Pays to Be Nice to People Investors in People: the Search for Measurable Benefits.” Personnel Review 27:143-155. doi:10.1108/00483489810369287.

Ercan, M. Kamil, M. Başaran Öztürk, ve Kartal Demirgüneş. 2003. Değere Dayalı Yönetim ve Entelektüel Sermaye. Ankara: Gazi Kitabevi.

Fraser, Stuart. 2003. "The Impact of Investors in People on Small Business Growth: Who Benefits?" Environment and Planning C: Government and Policy 21:793-812. doi:10.1068/c0304.

Gloster, Rosie, Tom Higgins, Annette Cox, ve Rebecca Jones. 2011. Exploring Employer Behaviour in relation to Investors in People. UK Comission for Employment and Skills Evidence Report 27.

Gloster, Rosie, Freddie Sumption, Tom Higgins, Annette Cox, ve Rebecca Jones. 2010. Perspectives and Performance of Investors in People: A Literature Review UK Comission for Employment and Skills Evidence Report 24.

Greener, Sue ve Tom Bourner. 2005. Investors in People: What's It All About? Brighton Business School, University of Brighton, Occasıonal/Woking Paper Series, Working Paper No: 5.

Grugulis, Irena ve Sheena Bevitt. 2002. "The Impact of Investors in People: A Case Study of a Hospital Trust." Human Resource Management Journal 12:44-60. doi:10.1111/j.1748-8583.2002.tb00070.x.

Hill, Rosemary ve Jim Stewart. 1999. "Investors in People in Small Organizations: Learning to Stay the Course?” Journal of European Industrial Training 23:286-299. doi:10.1108/03090599910284669

Hillage, James ve Janet Moralee. 1996. The Return on Investors, Report no. 314, Institute of Employment Studies London.

Hogg, Gillian, Sara Carter, ve Anne Dunne. 1998. "Investing in People: Internal Marketing and Corporate Culture.” Journal of Marketing Management 14:879-895. doi:10.1362/026725798784867563.

Kidger, Peter, Margot Jackson-van Veen, ve David Redfern. 2004. "Transferring the Investors in People concept from the UK to The Netherlands." Journal of Europen Industrial Training 28:499-518. doi: $10.1108 / 03090590410542729$.

Mason, Don. 1994. "Investors in People: Journey to Continuous Development." Health Manpower Management 20:8 -12. doi: 10.1108/09552069410060030.

Maxwell, G. A., MacRae, M., Adam M. ve Anna MacVicar. 2001. "Great expectations: Investors in People in Scottish tourism.” Total Quality Management 12:735-744. doi:10.1080/09544120120075343.

Michaelis, C. and McGuire, M. 2004. Investors in People: Impact Assessment, Databuild: Research and Solutions, Birmingham, UK.

O'Neill, Martin A. 1996. "Investing in People: a Perspective from Northern Ireland Tourism - Part I.", Managing Service Quality: An International Journal 6:36-40. doi:10.1108/09604529610145873.

Parker, Martin. 2000. Organizatıonal Culture and Identity: Unity and Division at Work. London: Sage.

Ram, Monder. 2000. "Investors in People in Small Firms Case Study Evidence From the Business Services Sector." Personnel Review 29:69-91. doi: 10.1108/00483480010295826.

Smith, Paul J. 2000. "Implementing Investors in People: a Case Study From the NHS." Journal of European Industrial Training 24:275-280. doi: 10.1108/03090590010372047. 
Smith, Alison Jane, Grahame Boocock, John Loan-Clarke, ve John Whittaker. 2002. "IIP and SMEs: Awareness, Benefits and Barriers." Personnel Review 31:62-85. doi:10.1108/00483480210412427.

Spilsbury, M., Moralee, J., Hillage, J. and Frost, D. (1995), Evaluation of Investors in People in England and Wales, Report no. 289, Institute for Employment Studies, London.

Watson, Tony ve Diane Watson. 1999. "Human Resourcing in Practice: Managing Employment Issues in the University." Journal of Management Studies 36:483-504. doi: 10.1111/1467-6486.00146.

Yereli, Ayşe Necef ve Gülşen Gerşil. 2005. Entelektüel Sermayeyi Ölçme ve Raporlama Yöntemleri, Yönetim ve Ekonomi Dergisi Cilt:12, Sayı:2, 17-29.

Yüksel, Öznur. 2007. İnsan Kaynakları Yönetimi. Ankara: Gazi Kitabevi. 
EK: IIP Standart Çerçeve

\section{IIP STANDARDI ÇERÇEVESİ}

\section{KURUMSAL PERFORMANSIN ARTTIRILMASINA YÖNELIK STRATEJILERIN GELIŞTIRILMESI}

\begin{tabular}{|l|l|}
\hline Gösterge 1: & $\begin{array}{l}\text { Kurumsal Performansı Arttıracak Bir Stratejinin Açık ve Net Bir Şekilde Tanımlanması ve } \\
\text { Anlaşılması. }\end{array}$ \\
\hline
\end{tabular}

\section{Kriterler:}

1. Üst Yönetim, kurumsal performansın arttırılmasını öngören bir stratejiyi destekleyen açık ve net amaç ve vizyona sahip olduğundan emindir.

2. Üst Yönetim, kurumun performansı objektif ve ölçülebilir nitelikte stratejik bir plana sahip olduğundan emindir.

3. Üst düzey yöneticiler temsilci gruplarla (eğer varsa) yapıcı ilişkilerin sağlandığından emin olurlar ve şirketin iş planını geliştirirken bu gruplara danışırlar.

4. Yöneticiler şirketin iş planını geliştirirken ve grubu ya da bireyleri ilgilendiren amaçları belirlerken sürece bireyleri nasıl dahil ettiklerini tanımlayabilirler.

5. Temsilci grupların üyesi olan kişiler, üst düzey yöneticilerin gruplarla yapıcı ilişkileri kurduğunu ve şirketin iş planını oluştururken bu gruplara danışıldığını doğrulayabilirler.

6. Bireyler, şirket içindeki rollerine uygun bir biçimde, ekiplerinin ve şirketin amaçlarını açıklayabilirler ve bu amaçları geliştirmede, gerçekleştirmede şirkete nasıl katkılar sağlayabileceklerini tanımlayabilirler.

\begin{tabular}{|c|c|}
\hline Gösterge 2: & Gelisim ve Öğrenimin Kurumsal Amacları Gerceklestirmeye Yönelik Planlanmas \\
\hline
\end{tabular}

\section{Kriterler:}

1. Üst düzey yöneticiler şirketin öğrenme ve gelişim ihtiyaçlarını, bunları karşılamada kullanılacak plan ve kaynakları, bunların belirli amaçlara nasıl bağlı olduğunu ve etkilerinin nasıl değerlendirileceğini açıklayabilirler.

2. Yöneticiler şirketteki ekiplerin öğrenme ve gelişim ihtiyaçlarını, bunları karşılamada kullanılacak plan ve kaynakları, bunların belirli amaçlara nasıl bağlı olduğunu ve etkilerinin nasıl değerlendirileceğini açıklayabilirler.

3. Bireyler öğrenme ve gelişim ihtiyaçlarının belirlenmesi ve bunları karşılamada kullanılacak aktivitelerin planlanması sürecine nasıl dahil edildiklerini tanımlayabilirler.

4. Bireyler öğrenme ve gelişim aktivitelerinin kendileri, ekipleri ve şirket için ne ölçüde katkı sağlayacağını açıklayabilirler.

Gösterge 3: $\quad$ Gelişim ve Öğrenim Sürecinin Bütün Çalışanlara Fırsat Eşitliği Sağlayacak Şekilde Düzenlenmesine ve Yönetilmesine Yönelik Stratejiler.

\section{Kriterler:}

1. Üst düzey yöneticiler, herkesin hem kendi performansını hem de şirketin performansı geliştirecek fikirlerle katkıda bulunabilecekleri bir ortam hazırlayacak stratejileri tanımlayabilirler.

2. Üst düzey yöneticiler bireylerin farklı ihtiyaçlarını saptayabilir ve herkesin ihtiyacı olduğu desteği bulmasını sağlayacak ve herkesin öğrenme ve gelişim için eşit firsatlara sahip olduğu bir ortamı oluşturacak stratejileri tanımlayabilirler.

3. Yöneticiler bireylerin farklı ihtiyaçlarını saptayabilir ve herkesin ihtiyacı olduğu desteği bulmasını 
sağlayacak ve herkesin öğrenme ve gelişim için eşit firsatlara sahip olduğu bir ortamı oluşturacak stratejileri tanımlayabilirler.

4. Bireyler, yöneticilerin herkesin ihtiyacı olan desteğe eşit bir şekilde erişimi olduğu konusuna ve eşit fırsatların bulunduğu, bireylerin performansını artıracak öğrenme ve gelişim ortamı oluşturma konusuna kendilerini adadığına inanırlar.

5. Bireyler, kendilerinin ve başkalarının performanslarını geliştirecek fikirler ile katkıda bulunmaları için nasıl desteklendiklerine dair örnekler verebilirler.

Gösterge 4: $\quad$ Yönetimin İhtiyaç Duyduğu ve Gelişmesi İstenen Nitelikler ile Yeteneklerin Açık ve Net Bir Şekilde Tanımlanması ve Anlaşılması.

\section{Kriterler:}

1. Üst düzey yöneticiler, yöneticilerin liderlik ve etkili bir şekilde yönetmek ve geliştirmek için ihtiyaç duyduğu bilgi, beceri ve davranışları ve yöneticilerinin bu yeterliklere sahip olmaları için ellerinde bulunan planları tanımlayabilirler.

2. Yöneticiler liderlik yapmak ve bireyleri etkili bir şekilde yönetip geliştirmek için sahip olmaları gerek bilgi, beceri ve davranışları tanımlayabilirler.

3. Bireyler, yöneticilerinin kendilerine liderlik yapmak ve etkili bir şekilde onları yönetip geliştirebilmek için ne yapması gerektiğini tanımlayabilirler.

\section{KURUMSAL PERFORMANSIN ARTTIRILMASINA YÖNELIK GERÇEKLEŞTIRIILEN UYGULAMALAR}

\begin{tabular}{l|l}
\hline Gösterge 5: & $\begin{array}{l}\text { Yöneticiler İnsanlara Liderlik Etme, İnsanları Yönetme ve İnsanların Gelişimlerinde Etkin } \\
\text { Olmuşlardır. }\end{array}$
\end{tabular}

\section{Kriterler:}

1. Yöneticiler liderlik, yönetim ve bireylerin gelişimi konularında ne kadar etkili olduklarını açıklayabilirler.

2. Yöneticiler, kendilerine düzenli aralıklarla ve uygun zamanlarda bireylerin onlar hakkında nasıl yapıcı eleştiriler verdiklerine dair örnekler verebilirler.

3. Bireyler yöneticilerinin liderlik, yönetim ve onları geliştirme konularında ne kadar etkili olduklarını açıklayabilirler.

4. Bireyler performansları hakkında düzenli aralıklarla ve uygun zamanlarda nasıl yapıcı eleştiriler aldıklarına dair örnekler verebilirler.

\begin{tabular}{|l|l|l|l}
\hline Gösterge 6: & İnsanların Kuruma Katkısı Gözlenmiştir ve Değerlendirilmiştir. \\
\hline
\end{tabular}

\section{Kriterler:}

1. Yöneticiler kişilerin şirkete yaptıkları bireysel katkıları nasıl tanımlayıp değerlendirdiklerine dair örnekler verebilirler.

2. Bireyler şirkete nasıl katkı sağladıklarına ve bu katkının şirketin performansı üzerinde nasıl pozitif etkiler yarattığına dair örnekler verebilirler.

3. Bireyler şirkete yaptıkları katkının nasıl tanındığı ve değerlendirildiğini açıklayabilirler.

Gösterge 7: $\quad$ İnsanların Karar Alma Süreçlerine Katılımları Yoluyla, Aidiyet Duygularının Gelişimi ve Sorumluluk Üstlenmeleri Teşvik Edilmiştir.

\section{Kriterler:}

1. Yöneticiler, hem bireysel hem de temsilci grupları aracılığıyla bireyleri karar verme sürecine dahil ederek, sahiplenme ve sorumluluk duygusunu nasıl teşvik ettiklerini tanımlayabilirler. 
2. Bireyler, kendilerinin, ekibin ve şirketin performansı üzerinde etkisi olan karar verme sürecine kendi pozisyonlarına uygun bir seviyede dahil olmaya nasıl teşvik edildiklerini tanımlayabilirler.

3. Bireyler, kendilerinin, ekibin ve şirketin performansını etkileyen kararları kendi pozisyonlara uygun bir seviyede sahiplenmeye ve sorumluluğunu almaya nasıl teşvik edildiklerini tanımlayabilirler.

\begin{tabular}{|c|c|}
\hline Gösterge 8: & İnsanlar Etkin Olarak Yeteneklerini Geliștirmiş ve Bilgilerini Arttırmışlardır. \\
\hline
\end{tabular}

\section{Kriterler:}

1. Yöneticiler bireylerin öğrenme ve gelişim ihtiyaçlarının karşılandığından nasıl emin olduklarını açıklayabilirler.

2. Bireyler öğrenme ve gelişim ihtiyaçlarının nasıl karşılandığını, ne öğrendiklerini ve bu öğrendiklerini kendi pozisyonlarında nasıl uyguladıklarını tanımlayabilirler.

3. Şirkette yeni olan ya da yeni bir pozisyona geçmiş olan kişiler, kendilerine verilen oryantasyonun daha iyi bir performans sergilemelerine olan katkılarını tanımlayabilirler.

\section{STANDARDIN KURUMSAL PERFORMANS ÜZERINDEKI ETKISININ DEĞERLENDİRILMESI}

Gösterge 9: $\quad$ İnsanlara Yapılan Yatırımlar Kurumsal Performansı Geliştirmiştir.

\section{Kriterler:}

1. Üst düzey yöneticiler şirketin öğrenme ve gelişim üzerine yapılan bütün zaman, para ve kaynak yatırımını tanımlayabilirler.

2. Üst düzey yöneticiler öğrenme ve gelişim aktivitelerinin şirketin performansını artırmada ne kadar etkili olduğunu, uygun olan durumlarda sayısal verilere dayanarak, açıklayabilirler.

3. Üst düzey yöneticiler kişilere yaptıkları yatırımın değerlendirilmesinin şirketin performansını geliştirmede stratejilerin belirlenmesinde nasıl kullanıldığını açıklayabilirler.

4. Yöneticiler öğrenme ve gelişim aktivitelerinin ekibin ve şirketin performansını nasıl geliştirdiğine dair örnekler verebilirler.

5. Bireyler öğrenme ve gelişim aktivitelerinin kendilerinin, ekibin ve şirketin performansını nasıl geliştirdiğine dair örnek verebilirler.

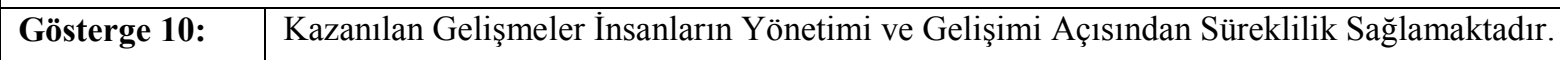

\section{Kriterler:}

1. Üst düzey yöneticiler kişilere yaptıkları yatırımın değerlendirilmesinin kişileri yönetmede ve geliştirmede şirketin kullanacağı stratejilerin belirlenmesinde nasıl sonuçlar doğurduğuna dair örnekler verebilirler.

2. Yöneticiler, yönetim ve kişilerin gelişimi üzerine kendilerine kattıkları gelişmelere dair örnekler verebilirler.

3. Bireyler, şirketin yönetim ve çalışanların gelişimi üzerine geçirmiş olduğu gelişim evrelerine dair örnekler verebilirler.

Not: www.tso.co.uk tarafindan yayınlanan "An overview of the Standard framework" den uyarlanarak oluşturulmuştur.

Erişim Linki: http://www.delni.gov.uk/iip_standardoverview1.pdf

Erişim Tarihi: 09/09/2014 